University of South Florida

DIGITAL COMMONS

Digital Commons @ University of

@ UNIVERSITY OF SOUTH FLORIDA

South Florida

Academic Services Faculty and Staff

Publications

Tampa Library

2012

\title{
Isn't Everything Online Yet? Streaming Media and Electronic Reserves
}

LeEtta M. Schmidt

University of South Florida, Imschmidt@usf.edu

Rue McKenzie

University of South Florida, rmckenzie@usf.edu

Follow this and additional works at: https://digitalcommons.usf.edu/tlas_pub

Part of the Library and Information Science Commons

\section{Scholar Commons Citation}

Schmidt, LeEtta M. and McKenzie, Rue, "Isn't Everything Online Yet? Streaming Media and Electronic Reserves" (2012). Academic Services Faculty and Staff Publications. 174.

https://digitalcommons.usf.edu/tlas_pub/174

This Article is brought to you for free and open access by the Tampa Library at Digital Commons @ University of South Florida. It has been accepted for inclusion in Academic Services Faculty and Staff Publications by an authorized administrator of Digital Commons @ University of South Florida. For more information, please contact digitalcommons@usf.edu. 


\section{Isn't Everything Online Yet?}

\section{Streaming Media and Electronic Reserves ${ }^{1}$}

Rue McKenzie and LeEtta Schmidt

University of South Florida

\footnotetext{
${ }^{1}$ This is an electronic version of an article published in the Journal of Interlibrary Loan, Document Delivery \& Electronic Reserve [ISSN: 1072-303x] @2011 copyright Taylor \& Francis; Journal of Interlibrary Loan, Document Delivery \& Electronic Reserve is available online at:

http://www.tandfonline.com/openurl?genre=article\&issn=15403572\&volume=22\&issue=3-4\&page $=175$
} 


\begin{abstract}
Libraries try several ways of meeting patron expectations. Providing on-demand streaming video content for course reserves remains a formidable challenge.

Multitudinous methods for acquiring and accessing content hamper the flexibility of any such service. This article reviews what one library has done to make streaming media, especially streaming video, available to faculty in the collection and how this foundation will be used to support electronic reserves service in the future.
\end{abstract}


Isn't Everything Online Yet? Streaming Media and Electronic Reserves

Browsing through academic library websites today, streaming media has a pervasive presence. While the availability of streaming video and audio has expanded dramatically in the past five years both in libraries and on the Internet in general, there continues to be almost as many approaches to acquiring and accessing commercially produced content as there are vendors. As a result the processes relating to streaming media can create challenges for libraries, and impact expectations regarding the services provided through e-reserves.

E-reserve is already well established in academic libraries, driven by student demand and distanced education courses that deliver lessons without any physical walls or structure. Programs developed to test the advantages of electronic reserves delivery have received overwhelming student approval (Hoppenfeld, 2010). Additionally, libraries have found that electronically delivered reserves get more readership and allow more students to access the content (Phinney, 2008). This precedent and user familiarity with accessing media online increases the expectation that any and all course content could be available online. Individual media types and purposes for the content carry with it specifically developed licensing practices. The licensing of video content especially is, as yet "only [a] vaguely defined concept and practice" (Handman, 2010 p325). There is no paved road to follow. Yet librarians in charge of media resources are expected to foray into this wilderness and uphold the library's commitment for media resources support (Spicer, 2010). Educators expect assistance integrating media into their courses regardless of format and media librarians are responsible for this support (Guidelines for Media Resources, 2012). 


\section{Experiences at the University of South Florida}

The USF Tampa library began acquiring commercially produced online audio in 2006, and online video in 2007 . Selection was based primarily on faculty requests and content we knew was historically used by faculty in their courses. This often provided an online version of heavily used physical content already in the media collection. These resources were added to the general online collection, and were accessible to authenticated patrons through the Library's OPAC. In most cases, faculty have also been able to add links to the Library's streaming titles to their Blackboard course content.

During our early period of streaming video acquisition, instructional design departments elsewhere on campus were providing limited assistance in delivering what would now be considered short term, locally processed online video content for course reserve. The Library focused on acquiring full length titles that could be accessed by all students, faculty, and staff.

Initially, additions of full length streaming video to the library collection were met with varied responses by faculty and students. As with the progression of print texts to electronic, media titles in online formats have been more successfully adapted to some disciplines over others. However, with the continued growth in online courses, large class enrollments, and increased use of media (particularly video) as a major component of instruction and research, broader accessibility to online media content became both expected and required. Given these considerations, selection of online video titles and databases to license has been based primarily on a combination of use 
patterns of video materials already in the physical media collection and consultations with faculty and collection development librarians.

In 2009, our Library partnered with the University's IT Classroom Technology Services and received funding for a 3-year Video Library On Demand (VLOD) Project to expand and enhance the Library's streaming video collection. Until that time, our licensing had been limited to streaming video titles and databases that were maintained and served by the vendors, such as Alexander Street Press and Films Media Group. The additional funding allowed us to expand our existing relationships with vendors, and also investigate a variety of new platforms and delivery options. The VLOD Project also provided the Library with an opportunity to add a diverse assortment of online video content in an effort to broaden our academic support and raise the profile of streaming video titles in our collection.

Streaming acquisitions prior to the VLOD Project focused on annual subscriptions, or 1 to 3 year licenses. The Project gave us the funding opportunity to proceed with discounted one-time purchases of perpetual rights for selected databases and single titles, rather than being limited to subscription/short term licensing options. The Project provided for technical support and expertise relating to streaming video processing, storage, and delivery. And, while full level cataloging has always been utilized for all purchased streaming content at the title, series, and/or database level, we received temporary part-time staff support which directly contributed to developing best practices for original and copy cataloging of streaming video as well as acquisitions records and libguide information dissemination. 
As the Project entered its final year, it became very clear that faculty and students expected increased support regarding online access to reserve media materials. The traditional reserve system requiring students to compete over limited physical copies of videos, coupled with expanded faculty requests for scheduled viewing in class of reserve videos, bolstered the argument for increased online access. At this point it also became clear that support areas on campus that historically had handled short term online video content in Blackboard were no longer involved in these digitization processes. As a result, faculty turned to the Library, not only to provide streaming video in the general media collection, but also assist in providing short term online reserve content that they had incorporated into their courses.

The Library was unprepared to successfully handle this new level of expectation, and efforts to partner with other areas on campus have not been successful to date. Similar to libraries surveyed by the Film Streaming Task Force at UC Irvine Libraries in 2010, we found that attempts at building/providing an in house collection of streaming media for course reserves was prohibitively time consuming and expensive (Allison, 2010). While video reserve processes traditionally involve purchasing one or more copies of commercially produced titles to be placed on reserve in the Library, providing the same content in a streaming format has proven to be much more challenging. Setting aside potential fair use interpretations, TEACH Act options and recent judicial rulings, obtaining digital licensing for extended use of entire video titles can be as simple as permission in writing from the rights holder to an agreed upon statement on the vendor invoice, or as arduous as a 10-page license agreement requiring University General Counsel signatures. Pricing can be just as varied, from something comparable 
to the cost of the corresponding institutionally priced DVD to four times as much. Both licensing and pricing can be dependent upon the extent of access needed, and the level of vendor support available. But that isn't always the case. There are vendors that host and serve streaming video comfortably through IP authentication for lower costs per title that those limited to selling the license to stream. In these cases, the library can expect to pay a summation of the cost of a hard copy, additional cost of the digital license, and the processing costs for extracting the video content, encoding, and uploading the video file to a secure server for proper IP authentication. Other vendors offer something in between, such as providing streaming files but requiring the material to be encoded and uploaded locally. In our experience, the process of acquiring access to a single streaming video program can range from as little as two hours up to over two months. It is important to note that online media content, related services, and pricing are regularly being modified by vendors in an effort to keep up with consumer expectations in order to remain relevant and competitive.

Some of the most difficult titles for libraries to provide in streaming video are feature films. We have found, as Gary Handman describes, that "delivery of theatrical feature films or home video titles exists in a separate market universe which ... bears little relationship to ... the library and school media marketplace" (2010 p325). Streaming licenses, when identifiable and available, are usually prohibitively expensive for libraries. Theatrical releases are regularly used in an academic setting, and the infinite range of possible titles makes it particularly difficult to anticipate requests. A service such as Swank Digital Campus (http://www.swank.com/digitalcampus/) can provide a level of support here for both short and long term flexible access. Because 
they work with a number of motion picture studios, the film selection is extensive. This service is specifically geared toward course reserve support. Given the breadth of licensing provided, this service may not fit well with every libraries' media budgets. Therefore, for courses with heavy film emphasis and a need for online support, we have started suggesting that faculty may want to refer their students to services such as Netflix, Amazon Video on Demand, or Hulu Plus. For educational and documentary streaming video, there are a number of open access options, such as Annenberg Learner (www.learner.org), Internet Archive/Moving Images (http://archive.org/details/movies), NOVA/PBS (http://www.pbs.org/wgbh/nova/), and PBS/FRONTLINE (http://www.pbs.org/wgbh/pages/frontline/view/). While open access online video is always expanding, it is important to note that some sites rotate their content. Therefore, faculty and students may not be able to rely on the availability of a specific title for long term or multiple viewings.

Considering the steps and costs involved in providing streaming versions of entire video programs, we have focused on longer term availability through the general collection, rather than short-term course reserve content only available through Blackboard. Faculty are encouraged to utilize the growing number of online videos in our collection, and when possible we respond to specific streaming requests on a title by title basis. In order for the library to successfully and efficiently serve faculty with media e-reserves, mandatory requirements include: 1) adequate and consistent funding ;2) clear understanding and support of copyright and licensing parameters ; 3) adequate equipment support and secure server space ; 4) sufficient number of staff with appropriate skill sets. 


\section{Moving ahead}

While the majority of the Library's streaming video collection is based on specific faculty requests or use patterns of the physical video collection, faculty and student expectations need to be met at a service front. The challenges of multiple platforms, time-consuming processes, and complex rights issues have meant most streaming reserves transactions are one at a time phenomena. This restricts patron use of the available resources and processes to those 'in the know,' a situation that is not tenable into the far future. The library's focus is turning more to the marketing of materials to faculty to promote awareness of collections currently available to all patrons. This is a task confronted by many libraries who have found permanent collection building of online media more viable than one time processing for e-reserves. Some have developed focus groups specifically to explore "the most effective means to support subject librarians and faculty member awareness of media resources to strengthen course integration" (Spicer, 2010 p92).

The drive to reach out to instructors and provide information on streaming media for use in courses comes at a time when the library is transforming its reserves services. Since first offering electronic reserves via the course management system at USF, processing of and support for book vs. media vs. electronic material type were kept separate. In the Spring of 2012, USF adopted the Ares reserves system to streamline faculty requests and staff processing. A unified service point for faculty naturally lent to gathering the staff into a team that would handle all book, electronic article, and physical media requests. Why not then add streaming media to the materials available? USF might not be able to provide routine on-demand streaming 
media reserves service at this time, but faculty would benefit from full knowledge of the material available and instructions for utilizing this material in their course management area.

It is important that we provide our patrons with this information as proactively and concisely as possible as part of continued support for an expanding service. A fully informed faculty will not only make better use of the streaming collection already built by the library, but may lead to partnerships that could pave the way for more on-demand streaming e-reserves service. A unified service point for all reserves, and processes that allow staff to quickly respond to faculty requests will ensure that instructor needs are addressed into the future.

\section{Works Cited}

"Guidelines for Media Resources in Academic Libraries (2012)", American Library Association, September 6, 2006.

http://www.ala.org/acrl/standards/mediaresources (Accessed September 13, 2012) Document ID: 9bce3971-1eb1-1c54-2191-7c3566164198

Handman, Gary. (2010). License to Look: Evolving Models for Library Video Acquisition and Access. Library Trends. 58(3), 324-334. Retrieved September 12, 2012 from: http://muse.jhu.edu/journals/lib/summary/v058/58.3.handman.html

Allison, Virginia. (2010). Streaming Media Informal Survey Summary. Survey Sent out Winter 2010 on behalf of the Film Streaming Task Force at UC Irvine Libraries. 
Phinney, Scott. (2008). Can't I Just Listen to That Online? Music Reference Services Quarterly. 9(2), 1-33. Retrieved September 11, 2012 from: http://dx.doi.org/10.1300/J116v09n02 01

Hoppenfeld, Jared and Arant-Kaspar, Wendi. (2010). Do-It-Yourself for Course Reserves: A Student-Driven Service in an Academic Library. The Journal of Interlibrary Loan, Document Delivery \& Electronic Reserve. 20(5), 353-361. Retrieved September 11, 2012 from: http://dx.doi.org/10.1080/1072303x.2010.520264

Spicer, Scott. (2010). A Framework for Media Resources Support Program Development. College \& University Media Review. 10, 79-90. Retrieved September 11, 2012 from: http://purl.umn.edu/130289 